\title{
The suppression of welcome
}

\author{
NICK GILL
}

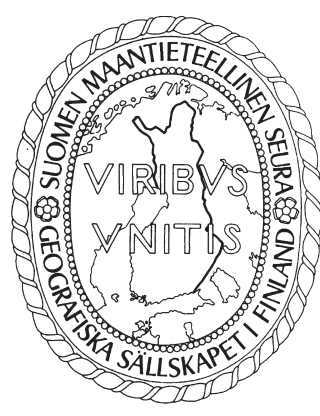

Gill, N. (2018) The suppression of welcome. Fennia 196(1) 88-98. https://doi.org/10.11143/fennia.70040

$\mathbf{y}$

One way to interpret the organisation of refugee welcome in Europe is by thinking about the tension between the official response and the grassroots response to the events. This tension has evolved in different ways in different countries, but in general it is possible to distinguish between a bureaucratic tendency to abstract welcome into a specific problem or policy domain, and a different, often opposite, tendency to welcome in spontaneous, solidaristic and autonomous ways. Starting from the premise that welcome necessarily entails more than simply permitting entry and is inherently emotional and relational, this lecture explores a series of questions. How can genuine, spontaneous welcome be preserved under the pressure of statist and nationalistic logics and demands? How can we hold onto welcome as something meaningful when it seems to be under attack from not only right-wing nationalists and factions that draw spurious connections between refugees and security threats, but also the very architecture of bureaucracy? What relationship does welcome share with legalistic logics and practices? To what extent can welcomers and welcoming initiatives be supported by international cooperation, global organisational and communication systems, and resource-gathering mechanisms? And what role can research play in improving our understanding of welcome? By raising these questions the lecture aims to initiate a discussion about the nature, practicalities and possible futures of welcome in geography and the social sciences more broadly.

Keywords: welcome, sanctuary, migration, refugees, asylum, hospitality

Nick Gill, Department of Geography, Amory Building, University of Exeter, Rennes Drive, Exeter, EX4 4RJ, UK. E-mail: n.m.gill@exeter.ac.uk

On the occasion of Finland's $100^{\text {th }}$ anniversary of independence the Annual Meeting of Finnish Geographer's conference 2017 chose the theme of 'Welcome to Finland'. Given the events of the preceding few years in relation to migration, and in particular Europe's response to the refugees displaced by unrest in the Middle East, this theme is extremely pertinent. It offers the opportunity to reflect upon the struggle over welcome in Europe.

A starting point is to recognise how poorly government policy reflects popular welcoming sentiments. A survey commissioned by Amnesty International (2016) asked more than 27,000 people in 27 countries globally about their attitudes towards refugees. Contrary to what the right-wing newspaper commentaries might have us believe, it demonstrated that government policy was out of step with the attitudes of most people, with two thirds of respondents stating that they thought their government should do more to help refugees ${ }^{1}$. This finding reflects badly on democracy ${ }^{2}$. Governments were either unwilling or unable to carry out the wishes of their electorates, who supported greater liberalisation of border controls and the delivery of more aid to those who had been displaced during a Creative Commons Attribution 4.0 International License. 
the so-called 'refugee crisis's. The result was that international aid efforts were under-supported. The United Nations High Commission for Refugees was able to raise only just over half of the required aid needed to respond to the humanitarian needs of the displaced by mid-2016.

Faced with the inertia of national governments and driven by strong discourses of compassion and solidarity, a range of grassroots organisations acted autonomously in Europe during 2014, 2015 and 2016, including delivering supplies, finding accommodation, offering medical, legal and educational support, and raising public awareness. They were galvanised by high levels of social media support, notably around the Twitter hashtag \#RefugeesWelcome, which rose to prominence following the publication of pictures of the drowned toddler Alan Kurdi, rapidly spread through other social media platforms, gained 'trending' status, filtered through into mainstream news media and ensured that 'Refugees Welcome' became a politically potent slogan (Barisione et al. 2017).

To be sure, these developments were not above reproach. The refugees in question were usually taken to be Syrians, which came to overshadow refugees fleeing other countries and situations, as well as the many millions of internally displaced people that did not or could not cross an international border and therefore did not qualify as refugees. As such the way that the refugee welcome movement was interpreted sometimes reflected a discursive narrowing even as it gained in popularity. Nevertheless, its sheer prominence meant that the 'refugee' question took centre stage in the collective consciousness of ordinary Europeans, shifting the matter of borders, in part at least, from a geopolitical issue framed by elite politicians and policy makers and approached via top-down interventions, to a geosocial issue (Mitchell \& Kallio 2017) framed by social media discourse and impacted by the collective agency of individuals. Alongside funds from the European Union, these events helped to alleviate the difficulties some countries faced in responding to increased numbers of migrants that needed support. As Rozakou $(2016,185)$ describes it with reference to the Greek case:

"In 2015, an unprecedented stream of material aid was transported to Greek islands from all over the world and different parts of Greece ... The recipients of these offerings were various solidarity initiatives and associations, some of which had recently emerged as a response to the huge numbers of people who crossed the Greek-Turkish sea borders. Delivery companies undertook the pro-bono transfer of parcels to non-governmental organisations (NGOs) and collectivities. A single transport company transferred more than 6,100 packages, weighing over 95 tons, between November 2015 and January 2016. Storehouses were full of clothes, food and other items. The Internet was flooded with crowd-funding campaigns by people from abroad who gathered contributions in order to travel and volunteer in different parts of Greece. Local groups already active in refugee assistance were startled by the amount of donations in objects and money, and the number and enthusiasm of new volunteers who came to join their activities. Tourists in the Greek islands decided to turn their vacations into the systematic assistance of border-crossers, distributed water and food or transferred people with their cars."

Many of these groups and initiatives had existed before 2015, but grew in number, magnitude and influence as the issue of refugee welcome gained prominence. The response has attracted some criticism for its inefficiency, the way it diverted resources away from the developing world, and the extent to which international humanitarian professionals rather than the Greek government or those working in the refugee sector before the increase in migrant arrivals had the final say on how to distribute the resources (Howden \& Fotiadis 2017). These incursions into the Greek management of the humanitarian response were commensurate with the crisis-fuelled establishment of European 'super-state' powers (Painter et al. 2017, 259) that culminated in the genesis of 'hotspots' as novel humanitarian devices fusing care and control ${ }^{4}$ (Tazzioli \& Garelli 2018). For all its misdirection, however, a high degree of solidarity was in evidence. 'Donations were so many that in autumn 2015', Rozakou recounts $(2016,196)$, 'collectivities in Lesvos had to ask publicly for a halt until they sorted and distributed the items they had accumulated'.

In the UK too, a marked tension arose between government responses and the activities of grassroots campaigns. When then Prime Minister David Cameron announced that the UK would only resettle an additional 20,000 Syrian refugees over five years in mid-2015, financial and material donations to refugee charities increased dramatically. The Charity City of Sanctuary, for example, a grassroots organisation committed to welcoming refugees, saw its British group membership double and its financial donations increase exponentially between early 2015 and $2017^{5}$. 
If the spontaneous welcome of refugees had been a response to the lacklustre efforts of many governments in Europe however, the EU-Turkey deal can be seen as a counter-measure: instituting a form of organisation of refugee reception that reinstated the old, familiar pattern of exteriorisation of border controls. The deal secured $€ 6$ billion to support Turkish assistance for refugees, and granted Turkish nationals visa-free travel to Europe. But it aimed to return every migrant arriving irregularly on the Greek islands back to Turkey ${ }^{6}$. It consequently re-established refugee reception as a matter of negotiation and calculation. This meant exposing asylum-seekers to unsafe conditions and inadequate legal safeguards (Amnesty International 2017), as well as turning the Greek islands into places of detention, containment and deportation?. Alongside heightened security measures in the Mediterranean, Europe's exteriorisation of refugee management hollowed out welcome itself.

One way to interpret the organisation of refugee welcome in Europe, then, is by thinking about the tensions between the official response and the grassroots response to the events. Distinguishing between institutionalised, statist ways of seeing and responding to events, and more organic, extemporaneous responses is key (see Magnusson 2013). This tension has evolved in different ways in different countries, but in general it is possible to distinguish between a bureaucratic tendency to abstract welcome into a specific problem or policy domain, and a different, often opposite, tendency - which is sometimes a reaction to the first - to welcome in spontaneous, solidaristic and autonomous ways.

How can genuine, spontaneous welcome be preserved under the pressure of statist and nationalistic logics and demands? How can we hold onto welcome as something meaningful when it seems to be under attack from not only right wing nationalists and factions that draw spurious connections between refugees and security threats, but also the very architecture of bureaucracy?

In these dilemmas about welcome we encounter the limits of bureaucracy itself, embedded in cold, efficient and impersonal rules that were conceived for the just administration of supposedly advanced, territorially contained societies, but which have come to form an 'iron cage' (Weber et al. 1930) that ultimately dehumanises, and restricts those very societies from developing beyond their origins. In what follows I discuss the various mechanisms that have threatened to suppress welcome in Europe (to varying degrees of success), in an attempt to throw into relief the workings of exclusionism and protectionism. Then I examine some of the questions these mechanisms raise for the movement towards welcome in Europe over the coming years, and conclude with a comment on the role of qualitative research in sustaining welcome. First of all, though, it is worth clarifying the essence of welcome itself.

\section{What is welcome?}

The distinction between orientating towards newcomers in terms of a set of laws, rules and obligations, and doing so in more impulsive, instinctive, emotionally-invested and inter-personal ways has animated debate about cosmopolitanism for some considerable time in the social sciences (Levinas 1979, 1981; Derrida 2001). On the one hand, 'hospitality' has been understood in terms of duties and rights (Derrida 2000). Scholars have argued that there is a connection between hospitality shown towards friend and enemy and hospitality itself has been thought of as the process of converting the latter into the former (Selwyn 2000). As such it entails serious risks and cannot be too warm, unguarded or enthusiastic. It has consequently often had a practical, rather than emotional, focus: emphasising the provision of food, drink and shelter (Lynch et al. 2011).

On the other hand, scholars who have studied welcome emphasise its emotional and relational character (Chauchard 1971; Gouirand 1991; LeBlanc 2000; Mouradian 2015). 'Feeling welcome' is induced by a perception that your presence brings about joy or satisfaction in someone else. Refugees' accounts of welcome often emphasise these inter-personal aspects. Consider the following account by a Syrian refugee housed in Germany who had waited for about a month for accommodation in 2015, and could not speak German:

"One day, a volunteer came to us to help us with everything. She's teaching us German and we call her Migy. I call her my German mother in my heart. I owe her a lot of things. It occurs to me that everyone here is smiling at us, but we are not smiling. It seems like we forgot how. It seems that in the end I didn't need food or money or even a safe country. All I needed was a good honest smile." (Jamous 2016) 
What is telling about this brief account is that the narrator values the human emotional element - the smile - extremely highly. Such intimacies ground global events (Pratt \& Rosner 2012). Moreover, the benefits of a genuine welcome such as this should be obvious: it creates the conditions for the development of mutual respect and trust, which is crucial to refugees' well-being (Lyytinen 2017).

Welcome is more than simply permitting entry. It involves conveying to the newcomer the positive reception of their presence. Welcome relies upon human warmth and, to a degree, the vulnerability of the welcomer. As such it cannot be mechanistic and unfeeling. Indeed, it may be impossible to welcome someone in an emotionally cold and disconnected manner since the emotional content is integral to the object of the encounter itself ${ }^{9}$. Welcome demands intimacy and occupies a world of inter-relational subjectivity and shared vulnerability; admission, on the other hand, speaks of permission and concession, occupying a world of economics and calculation.

Of course, this should not be taken to imply that all emotionality associated with questions of border control and migrant entry is of a welcoming nature. Distrust, political alienation and frustration with perceived ruling elites has also been linked to the rise of the political right in Europe as well as further afield in recent years (see Aisch et al. 2017). Working class, low skilled voters in many Western economies are facing unemployment, falling real wages, rising personal debt and a mismatch between their skills and the skills required by largely tertiary and quaternary industrial economies. The rise of right wing populism in the United States and Britain, for example, has been driven by structural changes in their economies that have made this social group feel disillusioned and politically unrepresented (Ford \& Goodwin 2014). Similarly in much of continental Europe, the economic difficulties of the late 2000s, including the sovereign debt crisis that erupted at the end of 2009, produced rising unemployment levels, fuelling right wing sentiments and increasing pressure on politicians to restrict numbers of immigrants, including asylum seekers and refugees (Greven 2016). Although radical right-wing parties are once again "a force to be reckoned with" (Akkerman et al. 2016, 3 ), the most notably feature of the right-wing parties that have benefitted from these developments is their strengthened mainstream appeal; policies and rhetoric that might once have been considered radically right-wing are becoming more acceptable and politically potent. While this lecture is concerned with the tension between bureaucracy and sentiments of welcome and inclusion then, it is worth noting that similar tension has animated the relationship between bureaucracy and protectionism in recent years.

\section{The mechanics of suppression}

With the emotional and relational character of welcome in mind, it is possible to outline a set of geopolitical and governmental factors that have threatened to suppress practical efforts towards welcome in Europe in recent years. Circumstances have not been favourable to the nurturing of the budding wave of welcoming sentiments that swept Europe in 2015. A series of events, from Brexit and the election of Donald Trump to the ascendance of the political party Alternative für Deutschland (Alternative for Germany, AfD) in Germany and the Paris attacks, have brought about a heightening of protectionist rhetoric in global politics and bolstered the momentum of the political Right, undermining confidence in openness generally.

Terrorism in particular should be highlighted as a factor that has suppressed welcome. While the political Right is often to be heard drawing associations between liberalism and the risk of terrorism, it is clear that terrorism has negatively impacted on the efforts of social liberals in Europe to create a safe and welcoming community. The operation of terrorists should therefore be conceptualised as an attack on openness and solidarity, since their very objective is to spread fear and mistrust. As with other, more everyday, forms of violence and fear that play a central role in the orchestration of contemporary political life (including the structural, hidden violences of neo-colonialism, discrimination and exploitation that underwrite the global economy - see Pain and Smith (2016)) the responses that they tend to elicit are typically those of recoil, withdrawal, closure and mistrust: all anathema to intimacy with others, all anathema to welcome.

In terms of governmental factors, I take government to refer to a broad set of mentalities of governing that may or may not coincide with the activities of nation-states. Central to the 
governmentality of welcome is the conceptualisation of the phenomenon of welcome in terms of policies and logistics, facilitated by a set of representational techniques including laws, statistics, demographics, charts, maps, surveys and expenditure. Spontaneous, emotional welcome is translated into these governmental forms via a process of abstraction.

From a geographical perspective, we might understand abstraction by distinguishing between 'abstract', 'planned' space on the one hand and what has been called 'lived' or 'everyday' space on the other (Lefebvre 1991, 2009). Lefebvre holds that abstract ways of organising space and social activity carry with them the risks of inattention or insensitivity to the concerns of real people and their everyday experiences. He calls these spaces, typically used by the 'scientists, planners, urbanists, technocratic subdividers and social engineers' (Lefebvre 1991, 38), 'lethal' (ibid., 370) because they seek to appropriate and subsume alternative ways in which space can be lived and organised. For Lefebvre, abstract spaces seek a translation from the represented to the concrete, such that concrete matters are to be arranged according to imagined notions of how social life should ideally proceed. The risk is that the representations are used to dominate and dictate reality: to 'reduce the lived to the conceived' (Lefebvre 2009, 229).

This sort of reduction can be counter-productive in the refugee context in at least two respects. First, the legalistic approach to welcome, in particular, typically obfuscates the complexity of human stories by subjecting them to classification, rendering them comparable and countable, assessing them for credibility and consistency, and presuming to be able to discern the most salient elements contained within them. Refugee narratives, filled with emotion, are distilled to bare facts (see Smith 2015). This makes the assumption that appeals against injustice and moral harms can be made without recourse to emotion and passion as key resources in conveying meaning. This assumption is becoming increasingly critically viewed in political theory (Shklar 1990; Barnett 2017). Having been thus formulated however, refugee experiences are assessed against a whole range of legal concepts, many of which are geographical (e.g. 'burden sharing', 'dispersal', 'vulnerable', 'territorial sovereignty', 'hotspots'). Whatever the official outcome of this process, there is a widespread, systematic underestimation of the consequences of undergoing it for the ability to live a full human life. Legal systems make temporal and spatial demands of their subjects that frequently become unbearable: including extended periods of waiting (Conlon 2011) $)^{10}$ and unrealistic requirements to either move or stay put (Hynes 2009).

A central pillar of the Common European Asylum System, for example, is the principle that an asylum claim received by a member state should be determined by the country in which it is first lodged ${ }^{11}$. This principle subordinates any desire to relocate to areas of the EU that may have greater capacity to welcome newcomers, or that may host concentrations of compatriot refugees, to bureaucratic and administrative convenience (Brekke \& Brochmann 2015). If asylum seekers are found to be claiming protection in the 'wrong' country they can be deported back to the country in which they first lodged a claim, with all the violence and disruption this entails. Germany, for example, carried out over 3,000 such deportations in the first half of 2017 alone (Su 2017). This policy acts not only as a form of literal containment of refugees at the external edges of Europe, but also a mechanism of estrangement and disconnection between many Europeans and asylum seeking newcomers. Unsurprisingly, it is a primary cause of migrants choosing clandestine approaches, as a way to autonomously reclaim their independence of movement (Tazzioli et al. 2014). Many refused asylum seekers have sought church asylum in Germany, for example, as a way to defy the 'first safe country' principle and have their claims determined in the German legal system (Su 2017).

The Dublin principle embodies a blunt application of a spatio-legal abstraction that is not attuned to the realities of migrants' lives. Instead it attempts to force them to contort themselves in uncomfortable ways in order to conform to an idealised spatial schema.

Another way in which the abstraction of welcome can be counter-productive is by paradoxically eliding humanitarianism and dehumanisation. Take the case of British Universities and refugee or asylum-seeking students. In 2012 British Universities offered 24 bursaries in total to refugee or asylum seeking students (Article 26 2018). By 2016 they offered 111 undergraduate and 29 postgraduate bursaries, an increase of over $400 \%$. It has allowed many of them to claim that they welcome refugees. But recent research has demonstrated that students from a refugee background in higher education 
in developed countries, including the UK, face a whole gamut of barriers and prejudices (Mangan \& Winter 2017). Educationally, very little provision is made for different styles of learning. Educators speak too fast, refuse requests for clarification, do not give refugees and asylum seekers the chance to speak in class, and mark their work down harshly for poor grammar or punctuation. Socially, asylum seeking and refugee students face racism and discrimination in the class and on campus. They are frequently not included in study groups and their ideas are routinely pushed aside. As a result they often study and eat alone.

An over-emphasis on numeric aspects of welcome over lived experiences undermines the basis of welcome itself. To be sure, the bursaries and scholarships are well-meaning, but they can easily become detached from the everyday life of students. As a result, the asylum seeking and refugee students in Mangan and Winter's (2017) research often did not feel welcomed at all, despite being formally admitted ${ }^{12}$.

The same pattern of humanitarian 'welcome' in an abstract sense, coupled with dehumanisation in practice, is discernible in various other contexts. Elisa Pascucci (2017) has identified the way in which contractions in material refugee aid are legitimated by humanitarian discourses of community- and self-help among refugees living in shelters in Cairo. Humanitarianism here masks real deficiencies in the ability to welcome refugees. In a different context, Ehrkamp and Nagel (2017) critically discuss the 'differential inclusion' (ibid., 318) of migrants in US churches: supported in highly conditional and selective ways which end up widening rather than reducing social inequalities. Their research illustrates how, when welcome is organised through institutions, it can become banal and ineffective (see also Mitchell 2017).

In general, a set of circumstances and governmentalities have created the conditions for the suppression of welcome as an inter-personal ethic in Europe. I do not want to suggest that welcome everywhere has been emptied of its meaning - this would overlook the continuing work of a whole range of highly effective grassroots organisations. At the same time it is important to recognise the threat of these circumstances and governmentalities, and to scrutinise the mechanics of their operation.

\section{Sustaining welcome}

This raises the question of how to respond to these developments from the perspective of sustaining and nurturing the movement towards welcome in Europe. In this section I reflect on the challenges confronting this movement, and pose some practical questions about how best to meet them in future years.

We need to be aware that spontaneous and autonomous work in everyday spaces of compassion and solidarity comes with its own difficulties. Some of the most striking instances of welcome in recent years have been south-south, refugee to refugee, welcome, such as Palestinian refugees in Lebanese camps welcoming Syrians (Fiddian-Qasmiyeh 2015), and Acehnese fishermen rescuing hundreds of displaced Rohingya who were stranded in the Andaman Sea in 2015 (Missbach 2015). Perhaps what we are seeing in these instances is the politicising and mobilising effect of shared vulnerabilities, driven by a recognition of mutual inter-dependence that is, paradoxically, harder for the rich, safe and powerful to partake in, or even acknowledge (Butler 2015). But these initiatives face real challenges in terms of their financial and material sustainability. Welcome can quickly become extremely sometimes prohibitively - costly to these communities.

Welcoming refugees necessitates certain aptitudes and resources, such as the ability to communicate with those being welcomed, the time to spend with them and, often, the interpersonal skills to interact appropriately with traumatised people. It is also true that not everybody will feel safe hugging survivors on the shores of Lesvos ${ }^{13}$ or befriending male detainees in Harmondsworth Immigration Removal Centre ${ }^{14}$ : there are important gender dynamics involved in the practicalities of welcome that are relatively underexplored. The image of the female body, and her baby, often prominently displayed in media representations of refugee 'crises', are regularly made to stand in for the voices and experiences of refugee women themselves ${ }^{15}$. Women and children are the spectacular victims of humanitarian crises, and yet their stories of migration remain obscured (Wright 2002; Alhayek 2014; Wolfe 2015). 
Welcoming also entails emotional labour that can often be undervalued. Asylum and refugee support groups constantly struggle with the burnout, depletion and secondary trauma of their personnel (Gill et al. 2012); and state bureaucracies routinely underestimate the risks of secondary trauma amongst their decision-makers (Gill 2016).

For these reasons it is vital to consider whether and how welcomers and welcoming initiatives can be supported by international cooperation, global organisational and communication systems, and resource-gathering mechanisms. Perhaps elements of the formal state system can and should be exploited and appropriated in the service of these goals? To abandon the state entirely as a hopelessly neoliberal or exclusionary phenomenon may be to 'cede too much' (Martin \& Pierce 2012, 67; Cooper 2017). Cooper (2017) suggests that we orientate towards the state not from a position of pure critique or negation, but with a view to nurturing its progressive elements. These include how certain Western developed states function to 'provide social welfare, steward resources, establish fora for public debate, make new, critical forms of knowledge possible and ... protect populations' (ibid., 338). Could the international state system ever be mobilised against the violence and wastefulness of border controls themselves ${ }^{16}$ ? If we are to defend welcome as an interpersonal ethic a balance must be struck between the necessity to maintain the human touch in order for welcome to be more than simply admittance, and the importance of finding resources and coordinating efforts in such a way as to make welcome sustainable and just, and to distribute its costs in ways that are equitable. Welcome needs to be both emotional and organisational, a tall order given the tendency of emotion to defy rationalistic calculation (Levinas 1981), and of bureaucratic organisation to evacuate personal emotion (Weber 1948). A progressive perspective on welcome might therefore highlight those instances in which this delicate balance has been struck at local, national and international scales ${ }^{17}$. The sanctuary movement is a concrete and lively example of such politics. By describing itself as simultaneously an organisation, a movement and a network it seeks to balance the need for organisational coherence with the importance of grassroots, local and interpersonal action and relationships (City of Sanctuary 2017).

\section{Conclusion}

This leaves us with a set of questions. Given that we can surely expect more international displacement of the scale recently witnessed in the years to come, where are we to look for progressive innovations in the arrangement and practice of welcome? How can we get better at protecting genuine welcome from its suppression via abstraction and bureaucracy? To what extent should states be engaged in efforts to organise welcome, given their place in the international state system that underpins exclusionary and subjugating border control in the first place? And how can the different ingredients of local, autonomous, spontaneous initiatives on the one hand, and globally coordinated, logistically sophisticated responses on the other, be effectively blended?

I want to end by examining the role that qualitative research can play in meeting some of these challenges. Research engages in representations of its own, and we should always be mindful of the representational politics involved in attempting to speak on behalf of others. Researchers are increasingly required to generate measurable and demonstrable impact, which can instrumentalise relationships between refugee communities and researchers in uncomfortable and inappropriate ways, contributing to the alienation of research subjects and to research fatigue (Sukarieh \& Tannock 2013). Refugee communities themselves have raised concerns about these risks and called for vigilance among those seeking to work with asylum seekers and refugees. They have requested that the principle 'nothing about us without us' is adhered to, and set out a series of considerations to highlight and minimise the ways in which bias and privilege can structure work with refugees (Canas 2015).

The challenge facing researchers, then, is to carry out their work in solidarity and partnership with participants, with careful consideration given to how refugees and their communities can be best presented and included in work, as well as how they might benefit from it. When approached in this way qualitative research can be an effective means of critique of the dehumanising tendencies inherent to bureaucracies of migration management and control. Research that gives space to refugee voices and experiences helps to develop a sharper focus on the emotional aspects of welcome by maintaining personalism and conveying nuance and contextual richness. For instance, following calls 
in social theory to attend more closely to grounded and felt injustices alongside abstract notions of justice (e.g. Shklar 1990; Barnett 2017), the corollary in the case of welcome is to undertake research into what precipitates feeling unwelcome (see Lynch 2017). This would be helpful in illustrating to bureaucrats and administrators the distinction between being admitted, and feeling as though your presence brought joy or satisfaction to someone else. By foregrounding welcome-as-experienced, qualitative research that is approached and executed carefully and sensitively can act to challenge some of the more abstract interpretations of welcome that underpin its governmentalisation.

\section{Notes}

${ }^{1}$ Europe was no exception, with an average of $67.8 \%$ of respondents either somewhat or strongly agreeing with the statement 'Our government should do more to help refugees fleeing war or persecution'. The European countries included in the survey were Spain, Germany, Greece, the UK, France and Poland.

2 The majority of the countries included in the survey would be widely recognised as democracies.

${ }^{3}$ There were exceptions. For example, Angela Merkel's Germany allowed many Syrian refugees entry initially, and Sweden accepted a high number of refugees relative to its population.

${ }^{4}$ Humanitarianism and saving lives has become more central to European borderwork itself over the last decade, in large part as a product of the obliteration of safe and legal routes out of conflict and away from human rights abuses or poverty, which produces a level of violence that states, including the European Union, must be seen to be responding to (Pallister-Wilkins 2016).

${ }^{5}$ I was a trustee of the national charity during this time.

${ }^{6}$ Although provision was made in the deal to relocate one Syrian refugee from Turkey to the EU for every Syrian returned from the Greek islands to Turkey, the rate of relocation to the EU was 'negligible', at least in the early phases of the deal (Amnesty International 2017,6).

${ }^{7}$ While it may be argued that it is unsafe for migrants to attempt to reach Greece irregularly from Turkey, an emphasis on facilitating safe and legal routes to Greece and further into Europe could have avoided the recourse to forcibly containing them in Turkey.

${ }^{8}$ In the opening editorial of the journal Hospitality and Society for example, the editors, in outlining their vision for a broad, intellectually inclusive approach to hospitality, make only brief reference to the emotions of hospitality (Lynch et al. 2011).

${ }^{9}$ This is why it is possible to talk about one computer platform 'hosting' another, but one cannot talk about a computer platform 'welcoming' another - the distinction is emotional.

${ }^{10}$ Although these are not always spent passively, and can be periods of - albeit limited - agency in asylum seekers' lives (Rotter 2016).

${ }^{11}$ This principle is to be found in the Dublin Convention and its subsequent amendments.

12 It is for these reasons that I and others have been involved in attempts to promote a more holistic approach to refugee welcome in Universities in recent years via an initiative called 'Universities of Sanctuary' (see Finlinson et al. 2016).

${ }_{13}^{13}$ I am indebted to Eeva Kemppainen and Tomi Haapa-Alho for this point.

${ }^{14}$ One of Europe's biggest Detention Centres, located in Britain.

${ }^{15}$ For work that is critical of the trope of 'crisis' as it comes to be applied to migration, see Mountz and Heimstra (2014), Lindley (2014) and Gill and Good (forthcoming).

${ }^{16}$ I reflect on this possibility in greater detail in a forthcoming book co-edited by Cooper, Dhawan, and Newman (forthcoming).

${ }^{17}$ Recent interest in 'emotional states' could be helpful in this regard (Jupp et al. 2016).

\section{Acknowledgements}

I am grateful to the organisers and attendees of the Annual Finnish Geographers' Conference 2017 in Turku, Finland. I am also grateful to Kirsi Pauliina Kallio and James Riding for their editorial assistance, Jen Bagelman and Matt Sparke who acted as referees in Fennia's open review process of this article and the members of the geography department at the University of Exeter who organised and 
attended the Changing Geographies discussion session at which I presented an earlier version. I acknowledge financial support from the European Research Council, grant number: StG-2015_677917; Acronym: ASYFAIR.

\section{References}

Aisch, G., Pearce, A. \& Rousseau, B. (2017) How far is Europe swinging to the right? The New York Times 23.10.2017 <https://www.nytimes.com/interactive/2016/05/22/world/europe/europe-rightwing-austria-hungary.html>. 18.05.2018

Akkerman, T., de Lange, S. L. \& Rooduijn, M. (2016) Inclusion and mainstreaming? Radical right-wing populist parties in the new millennium. In Akkerman, T., de Lange, S. L. \& Rooduijn, M. (eds.) Radical Right-wing Populist Parties in Western Europe: Into the Mainstream?, 1-28. Routledge, London.

Alhayek, K. (2014) Double marginalization: the invisibility of Syrian refugee women's perspectives in mainstream online activism and global media. Feminist Media Studies 14(4) 696-700. https://doi.org/10.1080/14680777.2014.935205

Amnesty International (2016) Refugees welcome survey 2016 - The results. <https://www.amnesty. org/en/latest/news/2016/05/refugees-welcome-survey-results-2016/>. 31.01.2018.

Amnesty International (2017) A Blueprint for Despair: Human Rights Impact of the EU-Turkey Deal. Amnesty International, London.

Article 26 (2018) Student Bursaries. <http://article26.hkf.org.uk/student-bursaries>. 31.01.2018.

Barisione, M., Michailidou, A. \& Airoldi, M. (2017) Understanding a digital movement of opinion: the case of \#RefugeesWelcome. Information, Communication \& Society [online Dec 08 2017] https://doi.org/10.1080/1369118X.2017.1410204

Barnett, C. (2017) The Priority of Injustice: Locating Democracy in Critical Theory. University of Georgia Press, Athens. https://doi.org/10.2307/j.ctt1pwt43v

Brekke, J.-P. \& Brochmann, G. (2015) Stuck in transit: secondary migration of asylum seekers in Europe, national differences, and the Dublin regulation. Journal of Refugee Studies 28(2) 145-162. https://doi.org/10.1093/jrs/feu028

Butler, J. (2015) Notes Toward a Performative Theory of Assembly. Harvard University Press, Cambridge. https://doi.org/10.4159/9780674495548

Canas, T. (2015) 10 things you need to consider if you are an artist not of the refugee and asylum seeker community looking to work with our community. RISE: Refugees, Survivors and Exdetainees. $\quad<$ http://riserefugee.org/10-things-you-need-to-consider-if-you-are-an-artist-not-of-therefugee-and-asylum-seeker-community-looking-to-work-with-our-community/>. 28.03.2018.

Chauchard, P. (1971) L'accueil. Editions Universitaires, Paris.

City of Sanctuary (2017) City of Sanctuary Charter 2017. City of Sanctuary, Sheffield. <https:// cityofsanctuary.org/2017/05/16/city-of-sanctuary-conference-and-agm-2017/>. 28.03.2018.

Conlon, D. (2011) Waiting: feminist perspectives on the spacings/timings of migrant (im)mobility. Gender, Place \& Culture 18(3) 353-360. https://doi.org/10.1080/0966369X.2011.566320

Cooper, D. (2017) Prefiguring the state. Antipode 49(2) 335-356. https://doi.org/10.1111/anti.12277

Cooper, D., Dhawan, N. \& Newman, J. (eds.) (forthcoming) Reimaging the State: The Challenge for Progressive Transformative Politics. Routledge, London.

Derrida, J. (2000) Of Hospitality: Anne Dufourmantelle Invites Jacques Derrida to Respond. Stanford University Press, Stanford.

Derrida, J. (2001) On cosmopolitanism. In Derrida, J. (ed.) On Cosmopolitanism and Forgiveness, 3-24 Routledge, New York.

Ehrkamp, P. \& Nagel, C. (2017) Policing the borders of church and societal membership: immigration and faith-based communities in the US South. Territory, Politics, Governance 5(3) 318-331. https://doi.org/10.1080/21622671.2017.1290545

Fiddian-Qasmiyeh, E. (2015) Refugees helping refugees: how a Palestinian camp in Lebanon is welcoming Syrians. <https://theconversation.com/profiles/elena-fiddian-qasmiyeh-192354>. 31.01.2018.

Finlinson, E., Grace, A. \& Gill, N. (2016) Universities of Sanctuary Resource Pack. City of Sanctuary, Sheffield.<https://universities.cityofsanctuary.org/wp-content/uploads/sites/68/2016/03/ Universities-Pack.pdf>. 19.05.2018.

Ford, R. \& Goodwin, M. J. (2014) Revolt on the Right: Explaining Support for the Radical Right in Britain. Routledge, London. 
Gill, N. (2016) Nothing Personal? Geographies of Governing and Activism in the British Asylum System. John Wiley \& Sons, Oxford. https://doi.org/10.1002/9781118315996

Gill, N., Conlon, D., Oeppen, C. \& Tyler, I. (2012) Networks of Asylum Support in the UK and USA: a Handbook of Ideas, Strategies and Best Practice for Asylum Support Groups in a Challenging Social and Economic Climate. University of Exeter, Exeter.

Gill, N. \& Good, A. (eds.) (forthcoming) Asylum Determination in Europe: Ethnographic Perspectives. Palgrave, London.

Gouirand, P. (1991) Origines et perspectives historiques de l'accueil. Téoros 10 3-9.

Greven, T. (2016) The rise of right-wing populism in Europe and the United States. Friedrich Ebert Foundation, Berlin. <http://www.fesdc.org/fileadmin/user_upload/publications/RightwingPopulism. pdf>. 28.03.2018.

Howden, D. \& Fotiadis, A. (2017) Where did the money go? How Greece fumbled the refugee crisis. The Guardian 09.03.2017 <https://www.theguardian.com/world/2017/mar/09/how-greece-fumbledrefugee-crisis>. 31.01.2018.

Hynes, P. (2009) Contemporary compulsory dispersal and the absence of space for the restoration of trust. Journal of Refugee Studies 22(1) 97-121. https://doi.org/10.1093/jrs/fen049

Jamous, H. (2016) Safe in Germany, a Syrian Refugee Learns to Smile Again. Syrian Observatory for Human Rights. <http://www.syriahr.com/en/?p=47466>. 18.05.2018.

Jupp, E., Pykett, J., \& Smith, F. M. (ed.) (2016) Emotional States: Sites and Spaces of Affective Governance. Taylor \& Francis, Oxford.

LeBlanc, M. (2000) Une étude exploratoire : vers une échelle de mesure de l'accueil touristique. Loisir \& Société 23(1) 197-215. https://doi.org/10.1080/07053436.2000.10715609

Lefebvre, H. (1991) The Production of Space. Blackwell, Oxford.

Lefebvre, H. (2009) Space and the State. In Brenner, N. \& Elden, S. (eds.) State, Space, World: Selected Essays, 223-253. University of Minnesota Press, Minneapolis and London.

Levinas, E. (1979) Totality and the Infinite: An Essay on Exteriority. Springer, Dordrecht. https://doi.org/10.1007/978-94-009-9342-6

Levinas, E. (1981) Otherwise Than Being or Beyond Essence. Springer, New York.

Lindley, A. (ed.) (2014) Crisis and Migration: Critical Perspectives. Routledge, Abingdon.

Lynch, P. (2017) Mundane welcome: hospitality as life politics. Annals of Tourism Research 64 174-184. https://doi.org/10.1016/j.annals.2017.04.001

Lynch, P., Molz, J. G., Mcintosh, A., Lugosi, P. \& Lashley, C. (2011) Theorizing hospitality. Hospitality \& Society 1(1) 3-24. https://doi.org/10.1386/hosp.1.1.3 2

Lyytinen, E. (2017) Refugees' 'journeys of trust': creating an analytical framework to examine refugees' exilic journeys with a focus on trust. Journal of Refugee Studies 30(4) 489-510. https://doi.org/10.1093/jrs/few035

Magnusson, W. (2013) Politics of Urbanism: Seeing like a City. Routledge, Abingdon.

Mangan, D. \& Winter, L. A. (2017) (In) validation and (mis) recognition in higher education: the experiences of students from refugee backgrounds. International Journal of Lifelong Education 36(4) 486-502. https://doi.org/10.1080/02601370.2017.1287131

Martin, D. \& Pierce, J. (2013) Reconceptualizing resistance: residuals of the state and democratic radical pluralism. Antipode 45(1) 61-79. https://doi.org/10.1111/j.1467-8330.2012.00980.x

Missbach, A. (2015) The Rohingya in Aceh: solidarity and indifference. University of Melbourne, Melbourne. <http://indonesiaatmelbourne.unimelb.edu.au/the-rohingya-in-aceh-solidarity-andindifference/>. 18.05.2018.

Mitchell, K. (2017) Freedom, faith, and humanitarian governance: the spatial politics of church asylum in Europe. Space and Polity 21(3) 269-288. https://doi.org/10.1080/13562576.2017.1380883

Mitchell, K. \& Kallio, K. P. (2017) Spaces of the geosocial: exploring transnational topologies. Geopolitics 22(1) 1-14. https://doi.org/10.1080/14650045.2016.1226809

Mountz, A. \& Heimstra, N. (2014) Chaos and crisis: dissecting the spatiotemporal logics of contemporary migrations and state practices. Annals of the Association of American Geographers 104(2) 282-390. https://doi.org/10.1080/00045608.2013.857547

Mouradian, C. (2015) The Art of Welcome: What are the Innovative Practices that Would Enhance the Guests' Experience in Luxury Hotels? The vision for the Front-Office. Skema Business School, University of Nice, Nice.

Pain, R. \& Smith, S. J. (2016) Fear: critical geopolitics and everyday life. In Pain, R. \& Smith, S. J. (eds.) Fear: Critical Geopolitics and Everyday Life, 19-40. Routledge, Abingdon. 
Painter, J., Papada, E., Papoutsi, A. \& Vradis, A. (2017) Hotspot politics—or, when the EU state gets real. Political Geography 60 259-260. https://doi.org/10.1016/j.polgeo.2017.02.012

Pallister-Wilkins, P. (2016) Humanitarian borderwork. In Günay, C. \& Witjes, N. (eds.) Border Politics: Defining Spaces of Governance and Forms of Transgressions, 85-106. Springer, Cham. https://doi.org/10.1007/978-3-319-46855-6 6

Pascucci, E. (2017) Community infrastructures: shelter, self-reliance and polymorphic borders in urban refugee governance. Territory, Politics, Governance 5(3) 332-345. https://doi.org/10.1080/21622671.2017.1297252

Pratt, G. \& Rosner, V. (2012) The Global and the Intimate: Feminism in Our Time. Columbia University Press, New York. https://doi.org/10.7312/prat15448

Rotter, R. (2016) Waiting in the asylum determination process: just an empty interlude? Time \& Society 25(1) 80-101. https://doi.org/10.1177/0961463X15613654

Rozakou, K. (2016) Socialities of solidarity: revisiting the gift taboo in times of crises. Social Anthropology 24(2) 185-199. https://doi.org/10.1111/1469-8676.12305

Selwyn, T. (2000) An anthropology of hospitality. In Lashley, C. \& Morrison, A. (eds.) In Search of Hospitality: Theoretical Perspectives and Debates, 18-37. Butterworth-Heinemann, Oxford.

Shklar, J. (1990) The Faces of Injustice. Harvard University Press, Cambridge.

Smith, K. (2015) Stories told by, for, and about women refugees: engendering resistance. ACME: An International E-Journal for Critical Geographies 14(2) 461-469. <https://www.acme-journal.org/index. php/acme/article/view/1174>.

$\mathrm{Su}, \mathrm{A}$. (2017) As German police attempt to deport refugees, hundreds of churches are trying to shelter them. <https://www.washingtonpost.com/world/europe/in-germany-churches-offerunofficial-asylum-for-muslim-refugees/2017/09/05/1c068b68-88e6-11e7-96a7-d178cf3524eb story. html?utm term $=.4$ ce4150e2a3a>. 31.01.2018.

Sukarieh, M. \& Tannock, S. (2013) On the problem of over-researched communities: the case of the Shatila Palestinian refugee camp in Lebanon. Sociology 47(3) 494-508. https://doi.org/10.1177/0038038512448567

Tazzioli, M., De Genova, N., Mezzadra, S. \& Garelli, G. (2014) Migrant struggles. New keywords: migration and borders. Cultural Studies 29 80-83.

Tazzioli, M. \& Garelli, G. (2018) Containment beyond detention: the hotspot system and disrupted migration movements across Europe. Environment and Planning D: Society and Space [online Feb 19 2018] https://doi.org/10.1177/0263775818759335

Weber, M. (1948) Politics as vocation. In Weber, M., Gerth, H. \& Mills, C. W. (eds.) From Max Weber: Essays in Sociology, 77-128. Routledge, London.

Weber, M., Parsons, T. \& Tawney, R. (1930) The Protestant Ethic and the Spirit of Capitalism. G. Allen \& Unwin, London.

Wolfe, L. (2015) The missing women of the Mediterranean refugee crisis. <http://www. womensmediacenter.com/women-under-siege/missing-women-of-the-mediterranean-refugee-crisis>. 28.03.2018.

Wright, T. (2002) Moving images: the media representation of refugees. Visual Studies 17(1) 53-66. https://doi.org/10.1080/1472586022000005053 